\title{
REDESAIN ALAT PENCACAH PAKAN PADA PETERNAKAN UD. MUJUR DESA GAYAMAN, MOJOANYAR, KABUPATEN MOJOKERTO
}

\author{
Maula Nafi ${ }^{*}$, Djoko Sulistyono ${ }^{2}$, Robianto $^{3}$ \\ 1,2,3 Fakultas Teknik Universitas 17 Agustus 1945 Surabaya, Jl. Semolowaru 45, Surabaya \\ *Penulis korespondensi; email: maula.nafi@untag-sby.ac.id
}

\begin{abstract}
Abstrak: Salah satu kegiatan pengabdian masyarakat yang sedang dikembangkan oleh Program Studi Teknik Mesin UNTAG Surabaya adalah redesain dari alat pencacah pakan pada peternakan sapi UD. Mujur, Desa Gayaman Kecamatan Mojoanyar, Kabupaten Mojokerto. Ada tiga permasalahan utama yang ditemukan. Permasalahan pertama adalah mesin pencacah tidak mampu mencacah bahan pakan secara maksimal karena desain alat pencacah yang kurang ergonomis. Sehingga solusinya adalah dengan meredesain alat pencacah, terutama pada komponen pisau pencacah pakan. Permasalahan kedua adalah terdapat beberapa komponen pada mesin yang rusak dan harus diganti, sehingga solusinya dengan mengganti komponen penyaring dan v-belt. Penyaring yang terdahulu terlalu kecil ukurannya sehingga hasil cacahan sulit keluar, membuat terperangkap di dalam mesin. V-belt yang terdahulu sudah terlalu kendor sehingga tidak bisa memutar mesin pencacah dengan maksimal. Permasalahan ketiga yaitu kurangnya pengetahuan dan keterampilan pekerja tentang mesin pencacah pakan. Solusinya, diadakan diskusi dan penyuluhan untuk mengedukasi para pekerja tentang seluk beluk mesin pencacah pakan, mulai dari prinsip kerjanya hingga perawatan mesinnya. Secara umum, kegiatan berjalan dengan lancar, membuat produktivitas peternakan meningkat, terutama pada sektor penyediaan pakan dan manajemen pemberian pakan.
\end{abstract}

Kata kunci: Alat pencacah pakan; bahan pakan; penyaring; penyuluhan; pisau pencacah; redesain; v-belt.

\begin{abstract}
One of the community service program that has been developed by department of mechanical engineering UNTAG Surabaya is the redesign of chopper machine for cattle fodder in the farm of UD. Mujur, Gayaman, Mojoanyar, Mojokerto. There were three problems found in the farm. The first one was the chopper machine cannot maximally chop the cattle fodder because of the design of the chopper component. Hence, the solution was to redesign the chopper component and the machine blade. The second problem was there were components that are damaged and should be replaced. The solution was to replace those components; filter and v-belt. The filter before had too small mesh so that the feed ingredient could not come out the machine. The new filter has the bigger mesh so that feed ingredient could come out the machine. The v-belt was replaced because the old one was too saggy so that the machine could not rotate clearly. The last problem was the workers' knowledge and skills to operate the chopper machine was minimum. We created a group discussion and counseling to educate the workers about the chopper machine; the principle of work and the machine maintenance. Overall, the program succeed. It increased the productivity of the farm, especially in the cow feed and cattle fodder management.
\end{abstract}

Keywords: Chopper machine; counseling; feed ingredients; filter; machine blade redesign; v-belt.

\section{PENDAHULUAN}

\section{Desa Gayaman Kecamatan Mojoanyar Kabu- paten Mojokerto}

Kecamatan Mojoanyar merupakan salah satu kecamatan yang terletak berbatasan dengan Ibukota Kabupaten Mojokerto. Dari luas wilayah 2360 $\mathrm{km}^{2}$ Kecamatan Mojoanyar, yang terdiri dari 1491 ha adalah lahan pertanian dan Non Pertanian 225 ha dan bukan pertanian 644 Ha. dengan kepadatan penduduk Kecamatan Mojoanyar sebanyak 50.591 jiwa terdiri dari 25.508 Jiwa laki-laki dan 25.083 jiwa perempuan. Desa Gayaman adalah salah satu desa di Kecamatan Mojoanyar Kabupaten Mojokerto yang mana sebagian besar mata pencaharian 
warganya adalah sebagai petani, peternak, kuli, dan tukang bangunan. Di Desa Gayaman, kegiatan peternakan yang paling besar adalah peternakan sapi pedaging yang dimiliki oleh sebuah Unit Dagang bernama UD. Mujur. Beberapa warga sekitar bekerja sebagai peternak di peternakan tersebut. (http://mojoanyar.mojokertokab.go.id/, diakses 8 Agustus 2019)

\section{Peternakan UD. Mujur}

Peternakan UD. Mujur adalah peternakan sapi pedaging dengan kapasitas maksimum 50 ekor sapi, yang dikelola oleh masyarakat sekitar. Ratarata jumlah sapi yang dibudidayakan sekitar 20 sampai 30 ekor, namun bisa meningkat drastis hingga 50 ekor untuk persiapan Hari Raya baik idul fitri maupun hari raya kurban.

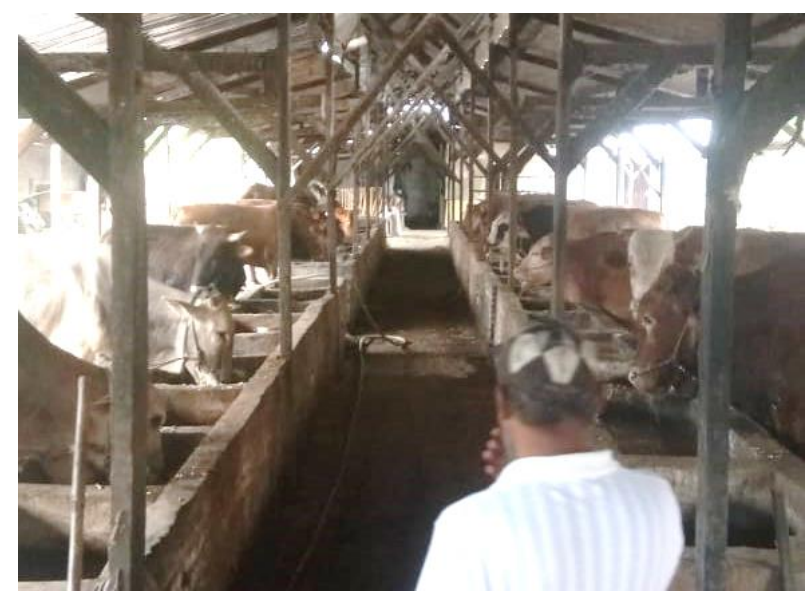

Gambar 1. Peternakan UD. Mujur

Para warga yang bekerja di UD. Mujur bertugas memandikan sapi, memisahkan kotoran sapi, dan memberi makan. Pakan yang diberikan bermacam-macam, dan UD. Mujur mempunyai mesin yang bisa digunakan untuk mencacah bahan pakan. Adapun bahan pakan dicacah adalah dengan tujuan untuk mempermudah sapi mencerna pakan. Adapun bahan pakan yang dapat dicacah adalah jerami atau kawul, tebon jagung, rendeng (batang) kedelai dan kacang, kulit kacang. Hasil survey pada peternak yang bekerja disana menyebutkan bahwa sapi akan meningkat nafsu makannya apabila pakan dalam ukuran kecil sehingga pakan dikonsumsi dengan mudah dan dalam jumlah yang banyak.

Peternakan UD. Mujur sebelas tahun terakhir ini telah menjadi lapangan pekerjaan yang dapat membantu meningkatkan ekonomi para pekerjanya yang mana merupakan warga sekitar peternakan. Oleh karenanya, dengan adanya peningkatan produktivitas pada peternakan ini, diharapkan mampu pula meningkatkan taraf hidup dan ekonomi warga sekitar Desa Gayaman.

\section{Permasalahan}

Permasalahan yang dibahas pada tulisan ini adalah adanya mesin pencacah pakan di peternakan yang tidak bisa dimanfaatkan secara maksimal. Mesin pencacah yang ada biasanya digunakan untuk mencacah bahan pakan gaplek atau singkong kering, mengecilkan ukurannya sehingga mempermudah sapi untuk memakannya. Gaplek merupakan salah satu bahan pakan bernutrisi tinggi yang mempercepat peningkatan berat sapi.

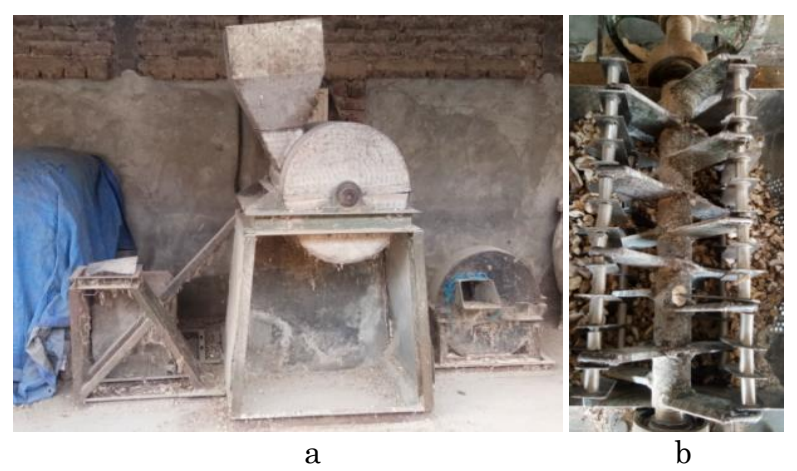

Gambar 2. a) mesin pencacah pakan; b) bagian dalam mesin pencacah pakan berupa pisau pencacah

Permasalahan pertama adalah gaplek yang tersedia (dipesan) adalah gaplek dengan ukuran besar (diameter 50 s.d. $100 \mathrm{~mm}$ ). pakan dengan ukuran tersebut akan susah dikunyah dan dicerna oleh sapi, sehingga ada proses pencacahan terlebih dahulu. Proses pencacahan hingga ukurannya kecil dapat diulang dua sampai tiga kali sehingga membutuhkan waktu dan tenaga untuk prosesnya (Sularso, 1997).

Permasalahan kedua adalah komponenkomponen yang sudah ada pada mesin pencacah sudah usang dan perlu adanya penggantian, seperti v-belt, dan filter atau penyaring pakan. V-belt yang mulai kendor menurunkan putaran mesin sehingga proses pencacahan tidak dapat berjalan maksimal. Penyaring pakan yang berkarat dan terlalu kecil membuat bahan pakan hasil cacahan susah untuk keluar dan tersumbat pada mesin sehingga membuat mesin sering stuck (Maitra, 2008).

Permasalahan ketiga adalah kurangnya pengetahuan dan keterampilan pekerja peternakan untuk menggunakan mesin pencacah, sehingga ketika mesin mengalami kerusakan sedikit, baik dari segi kelistrikan maupun pemesinannya, pekerja cenderung tidak mau memperbaiki dan mengoperasikannya kembali. Bahan pakan dengan ukuran besar langsung diberikan kepada sapi. Akibatnya, sapi cenderung tidak memakannnya karena sulit untuk dimakan dan dicerna.

Dari ketiga permasalahan diatas, dapat dikerucutkan bahwa permasalahan-permasalahan tersebut baik secara langsung maupun tidak langsung, 
mempengaruhi produktivitas peternakan. Baik dalam produksi pakan, rasio peningkatan bobot sapi, hingga keterampilan para pekerja.

\section{METODE PELAKSANAAN}

Metode yang digunakan untuk menyelesaikan permasalahan-permasalahan di Bab 1 adalah dengan metode observasi, kajian pustaka, dan penyusunan kegiatan countermeasure atau solusi untuk menyelesaikan permasalahan-permasalahan tersebut.

\section{Koordinasi Tim}

Tim pelaksana kegiatan ini terdiri dari dua orang dosen dan dua orang mahasiswa. Setiap anggota tim berdiskusi untuk menentukan job description masing-masing dan menentukan kegiatan apa saja yang dilakukan.

\section{Survey dan Observasi}

Pelaksana kegiatan melakukan survey di lapangan (peternakan UD. Mujur) baik pada mesin pencacah pakan maupun pada para pekerja di peternakan.

\section{Penentuan Kegiatan}

Tim menentukan bahwa kegiatan-kegiatan yang dilakukan untuk menyelesaikan permasalahan diatas adalah sebagai berikut:

1. Redesain mesin pencacah bahan pakan, terutama pada bagian-bagian yang membuat produktivitasnya menurun, yakni: a) pisau pencacah; b) v-belt penghubung dengan motor listrik; c) filter atau penyaring bahan pakan setelah dicacah.

2. Pengadaan kembali komponen-komponen yang di-redesain dengan hipotesis untuk meningkatkan produktivitas mesin pencacah bahan pakan

3. Penyuluhan dan demonstrasi prinsip kerja dan perawatan mesin pencacah pakan kepada para pekerja peternakan untuk meningkatkan keterampilan pekerja.

\section{Pelaksanaan Kegiatan}

Berdasarkan hasil survey dan observasi, penulis melakukan kegiatan pertama berupa redesain pencacah bahan pakan di kampus UNTAG Surabaya dengan menggunakan software desain dan berdasar literatur berupa buku Dasar Perencanaan dan Pemilihan Elemen Mesin (Sularso, 1997), serta berdiskusi dan mencari masukan dari dosen lain di Teknik Mesin dengan bidang keahlian desain dan manufaktur.
Hasil redesain berupa gambar dari komponenkomponen yang berpotensi untuk diganti. Gambar tersebut dibawa ke workshop untuk dibuatkan produknya sesuai dengan spesifikasinya. Komponenkomponen yang lain diadakan dengan membeli di toko peralatan dan perkakas.

Komponen-komponen yang baru dipasang pada mesin pencacah, kemudian dilakukan uji coba mesin dengan mencacah bahan pakan gaplek. Setelah hasil uji coba dinyatakan baik, penulis melakukan kegiatan terakhir yaitu penyuluhan dan demonstrasi mesin pencacah bahan pakan kepada pekerja yang ada pada peternakan UD. Mujur. Terakhir penulis melaksanakan serah terima komponen-komponen mesin yang sudah di redesain kepada peternakan.

\section{HASIL DAN PEMBAHASAN}

\section{Hasil Kegiatan}

Hasil kegiatan pertama berupa pelaksanaan redesain komponen-komponen mesin pencacah bahan pakan.
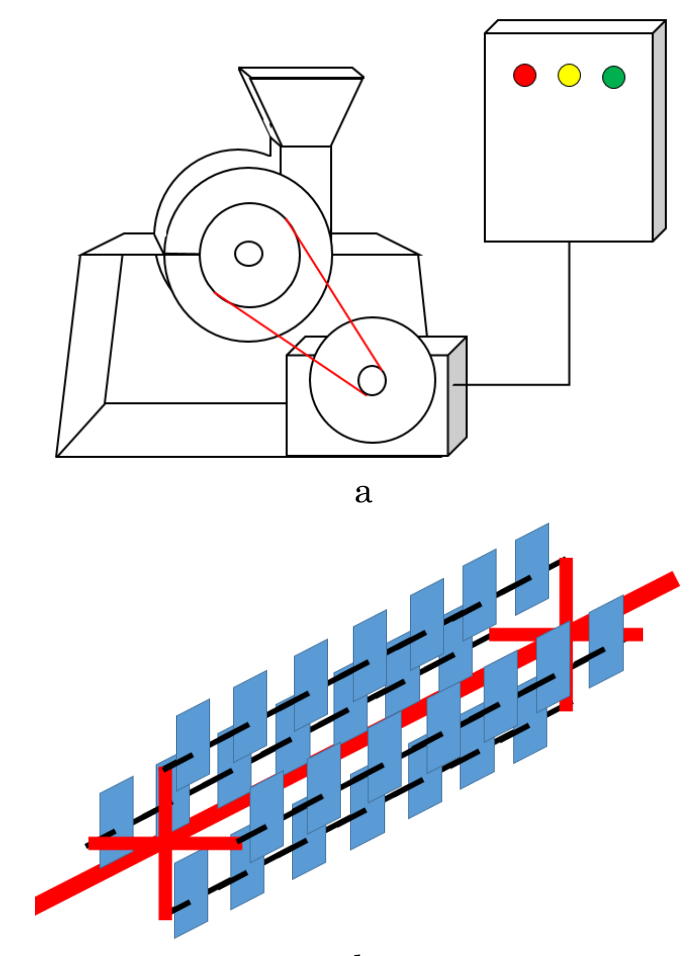

$\mathrm{b}$

Gambar 3. Desain komponen mesin pencacah pakan: a) pemasangan fan belt yang menyambungkan antara mesin dengan motor; b) pisau pencacah dengan empat sudu untuk mempercepat pencacahan dan memperkecil ukuran.

Berikut merupakan redesain dari bagian penyaring atau filter untuk menyaring hasil pencacahan dari mesin sehingga mempuyai ukuran yang kecil. 


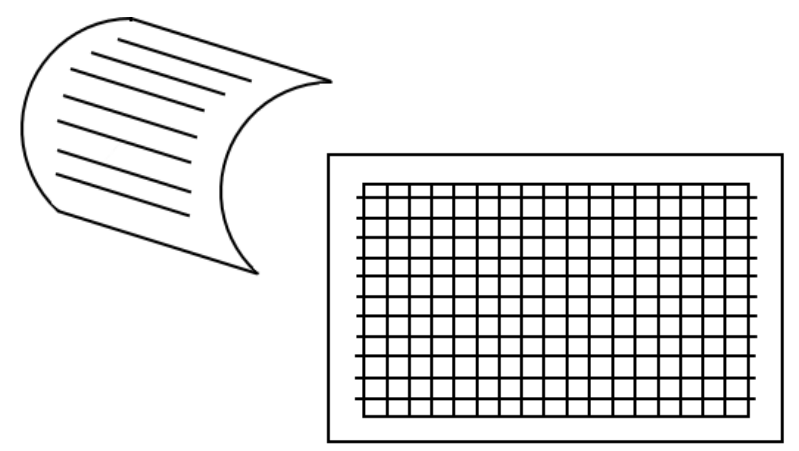

Gambar 4. Desain filter atau penyaring bahan pakan hasil cacahan

Hasil kegiatan kedua yaitu pengadaan dan pemasangan komponen-komponen yang di-redesain pada mesin pencacah, yaitu komponen: 1) pisau pencacah dengan empat mata pisau; 2) v-belt penghubung poros mesin dan motor penggerak; 3) filter bahan pakan hasil cacahan.

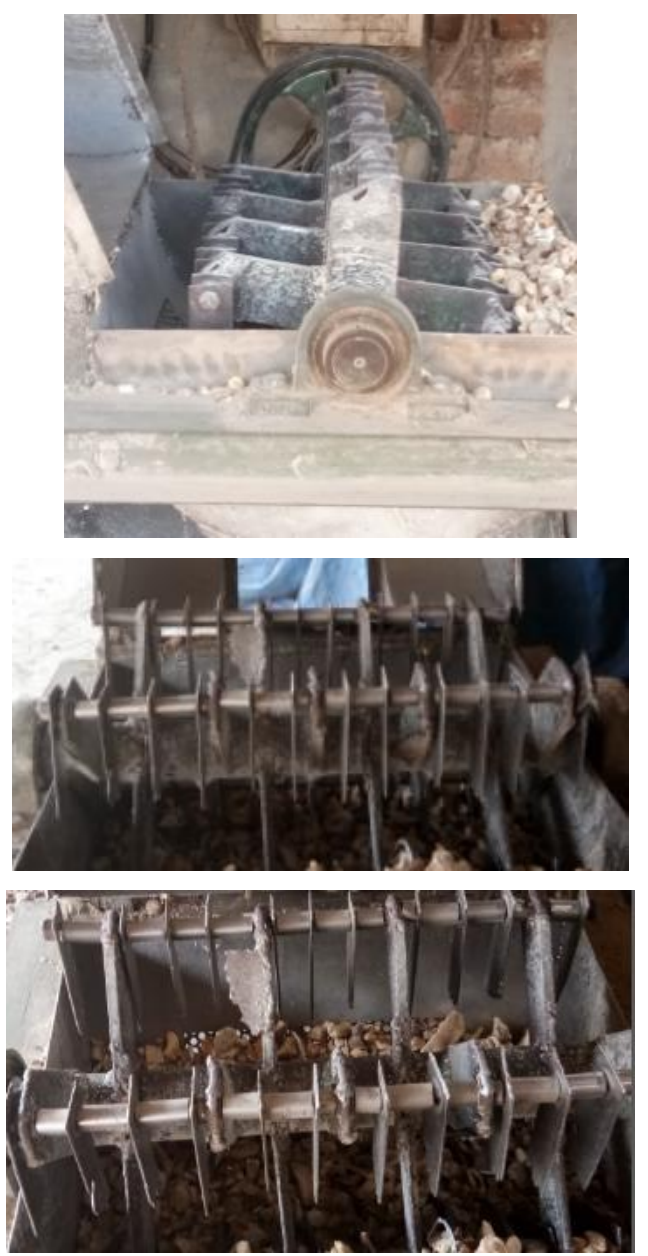

Gambar 5. Komponen pisau pencacah dengan empat mata pisau

Komponen pisau pencacah dengan empat mata pisau diharapkan mampu mempercepat proses pencacahan bahan pakan menjadi ukuran yang lebih kecil sehingga lebih mudah dikonsumsi oleh sapi (Rudenko, 2004).

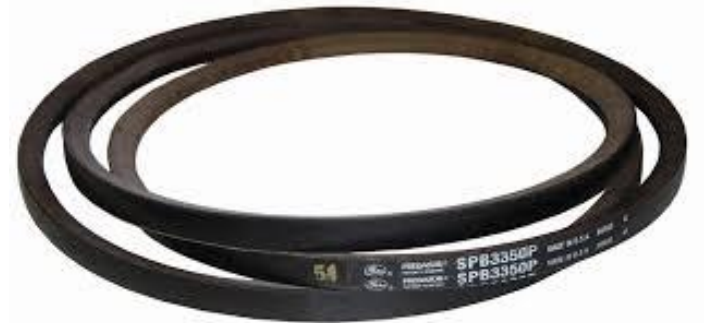

a

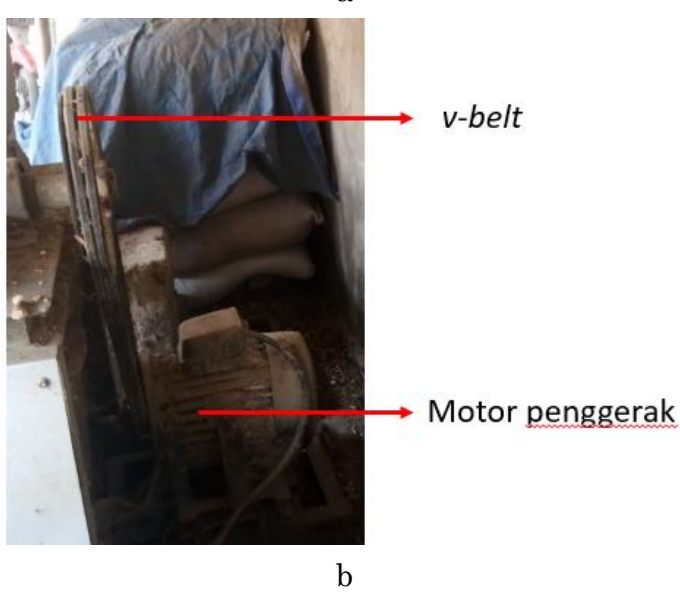

Gambar 6. a) v-belt penghubung mesin dengan motor penggerak; b) pemasangan $v$-belt pada pulley mesin dan motor penggerak

$V$-belt yang kendor tidak dapat mampu mengubah putaran motor penggerak menjadi putaran mesin dengan daya yang maksimal, sehingga proses pencacahan cenderung lama dan potensi tersendat sangat tinggi (Martin, 2011).
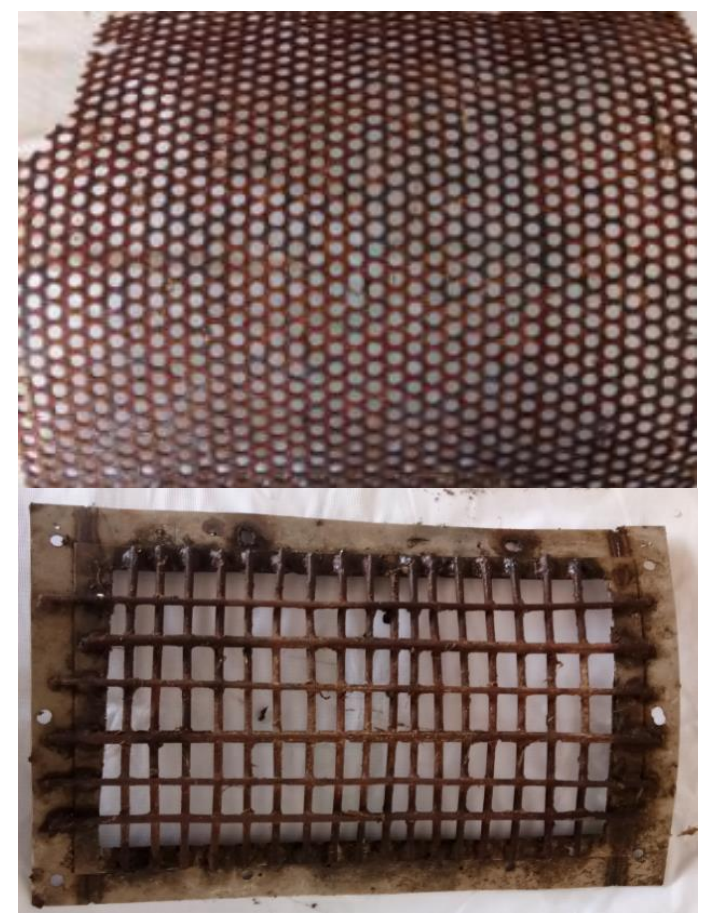

Gambar 7. Komponen filter hasil redesain dengan dua model saringan. 
Saringan dibuat dengan diameter yang lebih besar, sehingga mempermudah jalannya bahan pakan hasil cacahan untuk keluar. Sebelum diredesain, saringan terlalu kecil ukurannya, sehingga bahan pakan hasil cacahan sulit untuk keluar dan menyumbat membuat mesin stuck tidak bisa berputar.

Hasil kegiatan ketiga berupa kegiatan berupa penyuluhan dan demonstrasi prinsip kerja, penggunaan, dan perawatan mesin pencacah bahan pakan kepada para pekerja di peternakan. Tujuannya adalah untuk peningkatan pengetahuan dan keterampilan para pekerja, terutama dalam menggunakan mesin pencacah bahan pakan. Hal ini secara tidak langsung akan memberikan edukasi kepada para pekerja tentang bagaimana membuat pakan yang baik, serta peningkatan sense of belonging kepada tempat mereka bekerja karena telah diberikan pembelajaran dan edukasi.

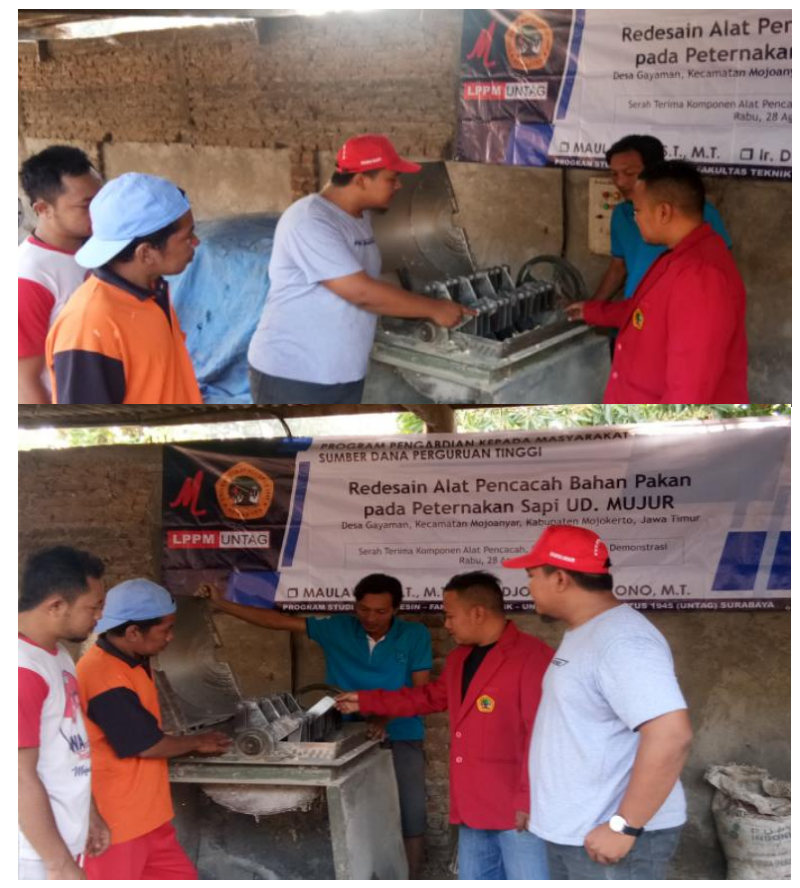

Gambar 8. Penyuluhan dan demonstrasi alat pencacah bahan pakan kepada para pekerja di Peternakan UD. Mujur

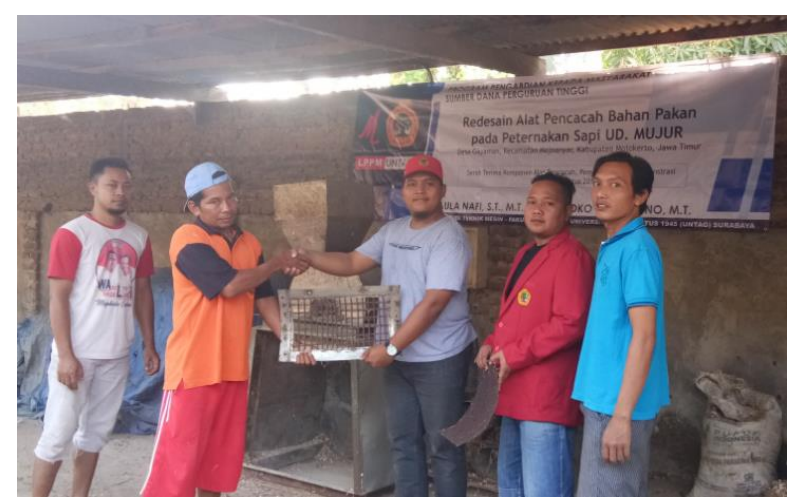

Gambar 9. Serah terima komponen alat pencacah bahan pakan secara simbolik kepada pekerja peternakan UD. Mujur

\section{Pembahasan}

Dengan terlaksananya kegiatan-kegiatan pada subbab 3.1, dapat diketahui terdapat perubahan yang signifikan terhadap produksi pakan di peternakan UD. Mujur. Sebelum adanya redesain dan pergantian komponen alat pencacah bahan pakan, proses pencacahan bahan pakan, terutama gaplek dilakukan dengan tiga kali pengulangan, sehingga memakan waktu yang lama, yaitu 40 sampai dengan 50 menit untuk satu sak gaplek, dengan berat kurang lebih $45 \mathrm{~kg}$. Pengulangan dilakukan karena ukuran gaplek hasil pencacahan pertama masih belum bisa membuat ukuran gaplek lebih kecil.

Setelah dilakukan redesain, pemasangan komponen-komponen baru, serta pelaksanaan demonstrasi, proses pencacahan gaplek yang awalnya memakan waktu 40 sampai 50 menit dengan tiga kali pengulangan, dengan ini dapat dipercepat menjadi 20 menit tanpa pengulangan. Hal ini dikarenakan komponen pisau pencacah lebih bisa mencacah gaplek dengan baik. Selain itu, dengan vbelt baru yang rapat dan tidak kendor, membuat putaran mesin yang bersumber dari motor listrik menghasilkan daya yang besar. Dibantu oleh filter penyaring dengan ukuran yang sesuai sehingga hasil cacahan langsung keluar dan tidak membuat mesin stuck. Bahan pakan hasil cacahan dapat dilihat pada gambar 10 .

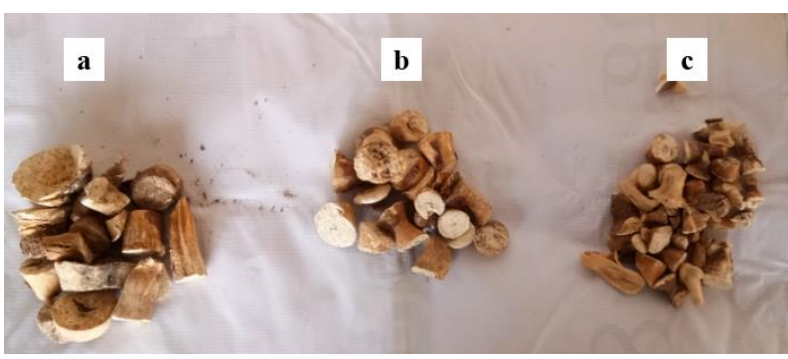

Gambar 10. a) dan b) bahan gaplek hasil cacahan sebelum mesin di-redesain, membutuhkan dua sampai tiga kali pengulangan; c) bahan gaplek hasil cacahan dengan mesin yang sudah di-redesain, hanya satu kali proses pencacahan.

Kegiatan penyuluhan berjalan dengan lancar, ditandai dengan banyaknya proses diskusi, tanya jawab, dan praktek dengan menggunakan mesin pencacah yang sudah di-redesain. Dengan adanya keseluruhan kegiatan ini, diharapkan peternakan UD. Mujur mampu meningkatkan produktivitasnya melalui pengolahan bahan pakan yang lebih baik.

\section{KESIMPULAN DAN REKOMENDASI}

Program redesain alat pencacah bahan pakan di peternakan sapi UD. Mujur Desa Gayaman Kecamatan Mojoanyar Kabupaten Mojokerto secara garis besar terdiri dari tiga kegiatan utama, yaitu: 
1. Redesain mesin pencacah bahan pakan, terutama pada bagian-bagian yang membuat produktivitasnya menurun, yakni: a) pisau pencacah; b) v-belt penghubung dengan motor listrik; c) filter atau penyaring bahan pakan setelah dicacah.

2. Pengadaan kembali komponen-komponen yang di-redesain dengan hipotesis untuk meningkatkan produktivitas mesin pencacah bahan pakan

3. Penyuluhan dan demonstrasi prinsip kerja dan perawatan mesin pencacah pakan kepada para pekerja peternakan untuk meningkatkan keterampilan pekerja.

Secara umum, kegiatan berjalan dengan sukses dan lancar, serta dapat menyelesaikan permasalahan-permasalahan yang terjadi pada peternakan, khususnya pengolahan bahan pakan dengan menggunakan mesin pencacah. Hasil redesain mesin pencacah mampu membuat proses pencacahan bahan pakan gaplek dua kali lebih cepat dan bahan hasil pencacahan yang lebih halus.

Rekomendasi untuk pengembangan kegiatan kedepannya adalah pelaksanaan perawatan alat dan mengembangkan berbagai macam pisau pencacah untuk berbagai macam dan jenis bahan pakan.

\section{UCAPAN TERIMA KASIH}

Terima kasih kepada Lembaga Penelitian dan Pengabdian Masyarakat (LPPM) Universitas 17 Agustus 1945 Surabaya yang telah memberikan dana hibah untuk pelaksanaan kegiatan pengabdian masyarakat ini. Terima kasih kepada Universitas Ciputra yang telah memberikan wadah untuk mempresentasikan hasil kegiatan ini pada Seminar Nasional Pengabdian Masyarakat 1. Terima kasih kepada LPPM Universitas Kristen Petra Surabaya yang memberikan kesempatan untuk publikasi artikel ilmiah terkait kegiatan pengabdian masyarakat ini pada Jurnal Share.

\section{DAFTAR PUSTAKA}

G.M. Maitra. 2008. Hand Book of Gear Design, Tata McGraw Hill, New Delhi.

George. H. Martin, Setyobakti. 2011. Kinematika dan Dinamika Teknik, Edisi Kedua, Erlangga, Jakarta.

http://mojoanyar.mojokertokab.go.id/, diakses 8 Agustus 2019.

Rudenko, N. 2004. Mesin Pengangkat, Erlangga, Jakarta.

Sularso, 1997. Dasar Perencanaan dan Pemilihan Elemen Mesin, Pradnya Paramita, Jakarta. 